\title{
The Effect of a Teacher-led Nutrition Education Program towards Anemia and Nutrition Status of Adolescent Girls in Bogor, Indonesia
}

\author{
Purnawati Hustina Rachman $^{1}$, Karina Rahmadia Ekawidyani ${ }^{1}$, Anna Vipta Resti Mauludyani ${ }^{1}$, \\ Judhiastuty Februhartanty ${ }^{2}$
}

\author{
${ }^{1}$ Departement of Community Nutrition, Faculty of Human Ecology, IPB University, Bogor, Indonesia \\ ${ }^{2}$ Southeast Asian Ministers of Education Organization Regional Centre for Food and Nutrition (SEAMEO \\ RECFON)/Pusat Kajian Gizi Regional Universitas Indonesia, Jakarta, Indonesia \\ Department of Community Nutrition, Bogor Agricultural University, Jl. Lingkar Kampus, Institut Pertanian Bogor, Dramaga, \\ Bogor, Indonesia 16680 \\ E-mail: hustinapur@apps.ipb.ac.id
}

Submitted: 11 March 2021, Revised: 9 April 2021, Accepted: 1 Mei 2021

\begin{abstract}
Nutrition education among adolescents is lacking in Indonesian schools. Whereas adolescent girls, in particular, need adequate nutrients to prepare them for their future pregnancy which may improve their nutrition status in the long term. Therefore, this study aims to assess the effect of a teacher-led nutrition education program on anemia and nutrition status of adolescent girls. A quasiexperimental design was applied in junior high and high schools in Bogor which compared the findings between the intervention $(n=112)$ and the control group $(n=129)$. Teachers in the intervention group received training on health and nutrition for adolescents and were asked to deliver nutrition education for their students for 14 weeks. The control group did not receive any exposure to the topics. The hemoglobin level, weight, and height were measured before and after the program among both groups. Paired and independent t-test statistical analysis was used to assess the impact of the intervention for continuous variables and the Chi-Square test was used for categorical data. After the program, although there were no significant improvements in BMI-for-age z-score, however, significant improvements were observed for hemoglobin level among the treatment group. This was consequently shown in the anemia status, where the prevalence of anemia was significantly lower compared to the control group $(p<0.001)$. The intervention group also showed better dietary diversity compared to the control group. The findings demonstrate that teacher-led nutrition education can improve the anemia status of adolescent girls.
\end{abstract}

Keyword: Teacher-led nutrition education, anemia, nutrition status, adolescent girls

\begin{abstract}
Abstrak
Pendidikan gizi di kalangan remaja masih kurang di sekolah-sekolah di Indonesia. Padahal remaja putri pada khususnya membutuhkan zat gizi yang cukup untuk mempersiapkan mereka menghadapi masa kehamilan yang dapat meningkatkan status gizinya dalam jangka panjang. Oleh karena itu, penelitian ini bertujuan untuk menilai efek program pendidikan gizi yang disampaikan oleh guru terhadap anemia danstatus gizi remaja putri. Sebuah desain kuasi-eksperimental diterapkan di SMP dan SMA di Bogor yang membandingkan temuan antara kelompok intervensi $(\mathrm{n}=112)$ dan kontrol $(\mathrm{n}=129)$. Guru pada kelompok intervensi mendapatkan pelatihan tentang kesehatan dan gizi bagi remaja dan diminta memberikan pendidikan gizi bagi siswanya selama 14 minggu. Kelompok kontrol tidak menerima paparan apapun tentang topik tersebut. Kadar hemoglobin, berat badan, dan tinggi badan diukur sebelum dan sesudah program pada kedua kelompok. Analisis statistik uji-t berpasangan dan independen digunakan untuk menilai efek intervensi untuk variabel kontinu dan uji Chi-Square digunakan untuk data kategori. Setelah program, meskipun tidak ada peningkatan yang signifikan pada IMT menurut umur, namun terdapat peningkatan yang signifikan pada kadar hemoglobin di kelompok intervensi. Hal ini terlihat pada status anemia dimana prevalensi anemia lebih rendah secara bermakna dibandingkan dengan kelompok kontrol $(\mathrm{p}<0.001)$. Hasil penelitian menunjukkan bahwa pendidikan gizi yang disampaikan oleh guru dapat memperbaiki status anemia putri.
\end{abstract}

Kata Kunci: Pendidikan gizi oleh guru, anemia, status gizi, remaja putri 


\section{Introduction}

Malnutrition in adulthood is mainly caused by malnutrition at the previous stage of the life cycle, i.e. adolescence. In many developing countries, early marriage and pregnancy in adolescents are still an issue (1). Moreover, the risk of maternal mortality in adolescents is slightly increased compared with women aged 20-24 years (2). Therefore, good nutrition in adolescents will improve the nutritional status during adulthood when they become a mother and in the long term will also improve the nutritional status of the child(s) they bore. Consequently, a nutrition program targeted to adolescent girls is highly required (3,4). Based on Indonesia Basic Health Research 2018 (5), the prevalence of stunting among adolescents was more than 25\%, wasting 8.7\% (aged $13-15$ years) and $8.1 \%$ (aged 1618 years), and overweight and obesity 16\% (aged 13-15 years) and 13.5\% (aged 16-18 years). Meanwhile, the prevalence of anemia among adolescent girls age 15-24 years was relatively high (32\%). Therefore, indicating the magnitude of nutritional problems among adolescents that requires sufficient attention.

Nutrition programs targeted at adolescent girls have been implemented in Indonesia, such as the iron supplementation program. Although the national coverage reached $76.2 \%$, however only $1.4 \%$ consumed more than 52 tablets or the recommended dosage (5). The short-term efficient supplementation approach, although technically feasible, has not been successful due to problems with delivery and compliance. Therefore, a combination with other interventions such as nutrition education to improve food habits might be beneficial. A school-based nutrition education program in China showed that the program had significant positive effects on nutrition-related knowledge, attitude, and behavior of adolescents compared to the control group (6). Another study in Malaysia showed that after six months of intervention to secondary school adolescents, nutrition education alone could increase hemoglobin level by $6.8 \%$, higher than supplementation $(1.0 \%)$, combination $(3.7 \%)$, and control $(-14.8 \%)$ groups. Furthermore, a significant improvement in knowledge and attitude was found in nutrition education and combination groups (7).

In Indonesia, nutrition education in schools is not included in national curriculum (8). The capacity of school teachers to deliver nutrition education is often not adequate, in terms of knowledge, confidence, and also time management (9). Whereas teachers are the potential to deliver nutrition education effectively to adolescents as they spend most of their time at schools and are also influential among students (10). Therefore, increasing the capacity of teachers is important to equip them with adequate resources to deliver nutrition education independently. Up to date, there is limited evidence on the impact of nutrition education on nutrition status and anemia prevalence among adolescent girls. To support the inclusion of nutrition education in schools, the current study aim to assess the effect of a teacher-led nutrition and health education program on the nutrition and anemia status of adolescent girls.

\section{Study Method}

A quasi-experimental study was conducted in Ciampea District, Bogor, Indonesia from March to November 2017. The intervention group consisted of one junior high school and two vocational high schools which were located in Cihideung Hilir Village. The village was specifically chosen as the program was implemented under the SEAMEO STAR Village, a capacity-building program for school teachers and related stakeholders initiated by six SEAMEO Centers in Indonesia (11). Meanwhile, the control group consisted of one junior high school and one vocational high school which was located in the same district. The control schools were chosen based on the recommendation from the District Education Office with the criteria of having similar social-economic characteristics and grade with the intervention schools. The inclusion criteria for both the intervention and the control schools were that have never received a nutrition and health program and willing to participate in the program for the full length of the study.

The population of the study was all students from the selected schools, as the program did not differentiate the delivery of nutrition education between boys and girls. However, subjects were adolescent girls' grade 7-8 from selected junior high schools and grade 11-12 from the selected vocational high schools who have given written consent from both themselves and their parents. 
Grade 9 and 10 were not included as subjects as most of them were not available during data collection. The minimum sample size was calculated using the formula for the comparison of two mean populations for hemoglobin level and also to compare two proportions for anemia prevalence. The difference in hemoglobin level of $1.03 \mathrm{~g} / \mathrm{dl}$ (12) with a 95\% confidence level and $90 \%$ power was used in the study and resulted in a minimum of 55 subjects per group. While a minimum difference of $25 \%$ was assumed to be required to detect a clinical change (13), which resulted in 91 subjects per group. With an estimated drop-out rate of $10 \%$, the minimum sample size was 100 subjects per group. In the current study, we recruited more subjects to cover outcomes reported elsewhere (14). Random sampling was applied to obtain sufficient numbers of subjects in both groups.

Teachers in the intervention group were invited to receive a two-day health and nutrition training provided by the researchers. The duration of the training was 7 hours per day. Topics introduced were based on the Adolescent Health and Nutrition Module (15) developed by SEAMEO RECFON. Part of the intervention package includes the module, close supervision and provision of additional education materials by researchers through WhatsApp Group, extended refresher training, and scheduled observational visits. Detailed information on the development of the module and the training is reported elsewhere (9). Information on the subject's characteristics were collected through a structured questionnaire which was administered by a trained enumerator. These include information on the age, grade, birth order, number of children in the family, number of family members, pocket money, parent's age, parent's education level and parent's occupation level.

Parameters collected were weight, height, and also hemoglobin levels. Weight was measured twice using the SECA weighing scale to the nearest $0.1 \mathrm{~kg}$. Subjects were asked to remove their shoes, jackets, and items in their pockets before being weighed. The position of the hand was loose and they were asked to look straight ahead during measurement. Meanwhile, height was measured twice using a universal ShorrBoard ${ }^{\circledR}$ to the nearest $0.1 \mathrm{~cm}$. Trained enumerators, who were at least nutrition bachelor students in their final year, conducted anthropometric assessments and also interviewed the subjects. BMI for age z-score was calculated using WHO Plus software and categorized using the WHO reference values for nutritional status (16). Hemoglobin level was assessed using HemoCue $\mathrm{Hb}$ 301 by a licensed medical doctor. Anemia was defined by having a hemoglobin level of less than 12 $\mathrm{g} / \mathrm{dl}(17)$.

Data were analyzed using the statistical software SPSS version 21 for windows. KolmogorovSmirnov normality test was used to assess the distribution of the data. Normally distributed data were presented in mean $\pm \mathrm{SD}$, while unequally distributed data in median (minimum, maximum). Categorical data were presented in $\mathrm{n}(\%)$. Comparison between the treatment and the control group at baseline and end-line used independent $t$-test analysis for continuous normally-distributed variables, while Mann-Whitney was used for non-normally distributed data. Chi-square was used to differentiate categorical data. To confirm the findings while taking into account potential confounding factors, a logistic regression controlling for grade, mother's and father's education level; and pocket money was applied. The study obtained ethical approval from the Faculty of Medicine, University of Indonesia (451/UN2.F1/ETIK/2017).

\section{Result and Discussion}

This study analyzed the impact of a teacher-led health and nutrition education program on the nutrition and anemia status of adolescent girls. The number of subjects in the study was 241, comprised of 112 adolescent girls in the intervention group and 129 in the control group which fulfills the minimum sample size. Subjects who were included in the analysis were those whose data were complete at baseline and end-line.

\section{Characteristics of subjects}

In general, there were significant differences in some characteristics of subjects between the intervention and control group before nutrition education (Table 1). The age of subjects in the intervention group was significantly higher than the control group $(\mathrm{p}=0.001)$. There were more subjects in grades 11 and 12 in the intervention group $(p<0.001)$. On average, subjects in the intervention group were the first children in the family, while subjects in the control group were the second children, however, no significant differences were found. The main differences in the age, 
grade, and birth order were due to the limited availability of 12-grade students in the control group because during the time of data collection they also had to do an internship. Therefore, the average age of the intervention group was older compared to the control. There were no differences in the number of children in the family, which on average were 3 family members, and also the number of a family member, which ranges from 4-5 members.

Pocket money per day of the control group was significantly higher than the intervention group. The highest proportion $(42.9 \%)$ of the intervention group had pocket money between IDR $15,001-20,000$, while the highest proportion $(41.1 \%)$ of the control group had pocket money between IDR 10,001-15,000 (USD 0.69-1.03) per day. There were no differences in father and mother age. However, father and mother education in the intervention group was higher than in the control group. Although most mothers graduated from elementary school in both groups, more mothers graduated from junior high school, senior high school, and university in the intervention group. Similar results were also found on the father's level of education. Almost all mothers of subjects in the intervention $(83.3 \%)$ and control groups $(84.1 \%)$ were housewives. Fathers of subjects in the intervention group mostly worked as sellers/entrepreneurs, including the owner of a car repair shop, car rental, and motorcycle leasing. While in the control group it was dominated by other types of occupation (28.2\%), such as (building contractor, foreman, factory labor, transport manual labor, workshop mechanics, security guard, shopkeeper, waiter, painter, debt collector, and head of sub-village). Moreover, a high proportion of fathers also work as service provider (motorcycle bike driver, car driver, tailor, washing laborer, laundry and agriculture/fishery/livestock farm laborer) and others.

Table 1. Characteristics of Subjects

\begin{tabular}{|c|c|c|c|}
\hline Characteristic & $\begin{array}{l}\text { Intervention } \\
(\mathrm{n}=112)\end{array}$ & $\begin{array}{l}\text { Control } \\
(n=129)\end{array}$ & p value \\
\hline Age (tahun), med (min, $\max )$ & $16(13,17)$ & $13(11,17)$ & $<0.001 *$ \\
\hline Grade, $\mathrm{n}(\%)$ & & & $<0.001 *$ \\
\hline - Grade 7 & $4(3.6)$ & $69(53.5)$ & \\
\hline - $\quad$ Grade 8 & $0(0.0)$ & $5(3.9)$ & \\
\hline - $\quad$ Grade 11 & $69(61.6)$ & $55(42.6)$ & \\
\hline - $\quad$ Grade 12 & $39(34.8)$ & $0(0.0)$ & \\
\hline Birth order, med (min, max) & $1(1,6)$ & $2(1,8)$ & 0.182 \\
\hline $\begin{array}{l}\text { Number of children in the family, med } \\
\text { (min, } \max \text { ) }\end{array}$ & $3(1,7)$ & $3(1,8)$ & 0.186 \\
\hline $\begin{array}{l}\text { Number of family members, med (min, } \\
\max \text { ) }\end{array}$ & $5(3,10)$ & $4(2,10)$ & 0.094 \\
\hline Pocket money per day, n (\%) & & & $<0.001 *$ \\
\hline - $\quad$ Rp 5000-Rp 10000 & $11(9.8)$ & $31(24.0)$ & \\
\hline - $\quad$ Rp 10001-Rp15000 & $13(11.6)$ & $53(41.1)$ & \\
\hline - $\quad$ Rp 15001-Rp 20000 & $48(42.9)$ & $37(28.7)$ & \\
\hline - $\quad>$ Rp 20000 & $40(35.7)$ & $8(6.2)$ & \\
\hline Age of mother (year), med (min,max) & $40(30,65)$ & $40(27,65)$ & 0.407 \\
\hline Age of father (year), med (min,max) & $44(30,65)$ & $45(30,72)$ & 0.569 \\
\hline Education level of mother & & & $0.006^{*}$ \\
\hline - Elementary & $50(45.9)$ & $85(68.0)$ & \\
\hline - Junior high & $29(26.6)$ & $23(18.4)$ & \\
\hline - Senior high & $27(24.8)$ & $16(12.8)$ & \\
\hline - Higher education & $3(2.8)$ & $1(0.8)$ & \\
\hline Education level of father & & & $<0.001 *$ \\
\hline - Elementary & $29(27.9)$ & $60(50.8)$ & \\
\hline - Junior high & $21(20.2)$ & $33(28.0)$ & \\
\hline \multirow[t]{2}{*}{ - $\quad$ Senior high } & $49(47.1)$ & $23(19.5)$ & \\
\hline & $5(4.8)$ & $2(1.7)$ & \\
\hline
\end{tabular}




\begin{tabular}{|c|c|c|c|}
\hline Characteristic & $\begin{array}{l}\text { Intervention } \\
(\mathrm{n}=112)\end{array}$ & $\begin{array}{c}\text { Control } \\
(n=129)\end{array}$ & p value \\
\hline $\begin{aligned} & \text { - } \text { Higher education } \\
& \text { Mothers' occupation } \\
& \text { - } \\
& \text { - } \text { Fnemployed/ housewife } \\
& \text { - } \text { Household Helper } \\
& \text { - } \text { Civil Servant/Army/ Police } \\
& \text { - } \text { Private company staff } \\
& \text { - } \text { Seller } \\
& \text { - } \text { Services (driver) } \\
& \text { - } \text { Others }\end{aligned}$ & $\begin{array}{l}90(83.3) \\
2(1.9) \\
0(0.0) \\
4(3.7) \\
0(0.0) \\
7(6.5) \\
0(0.0) \\
5(4.6)\end{array}$ & $\begin{array}{l}106(84.1) \\
1(0.8) \\
4(3.2) \\
0(0.0) \\
2(1.6) \\
7(5.6) \\
1(0.8) \\
5(4.0)\end{array}$ & 0.125 \\
\hline $\begin{aligned} & \text { Fathers' occupation } \\
& \text { - } \text { Farmer } \\
& \text { - } \text { Construction worker } \\
& \text { - } \text { Civil Servant/Army/ Police } \\
& \text { - } \text { Private company staff } \\
& \text { - } \text { Seller } \\
& \text { - } \text { Pension } \\
& \text { - } \text { Services } \\
& \text { (driver/laundry/laborer) } \\
& \text { - } \text { Others }\end{aligned}$ & $\begin{array}{l}4(3.9) \\
13(12.7) \\
6(5.9) \\
19(18.6) \\
24(23.5) \\
2(2.0) \\
14(13.7) \\
20(19.6)\end{array}$ & $\begin{array}{l}10(8.5) \\
27(23.1) \\
0(0.0) \\
16(13.7) \\
17(14.5) \\
1(0.9) \\
13(11.1) \\
33(28.2)\end{array}$ & $0.014^{*}$ \\
\hline
\end{tabular}

In terms of social-economic status, the intervention group has more advantage in parent's education level and pocket money, indicating that the findings of this study must be carefully interpreted. In several studies, it is known that higher education of parents has better influences on the children's diet. As the diet of adolescents is partially contributed by what is served at home and affected by the family's dietary pattern (18), hence it may also affect the outcome. Meanwhile higher economic status, indicated by higher pocket money also provides advantages in terms of wider food choice and better access to nutritious food (19). However, in this study, the baseline conditions of the main outcomes (anemia dan nutrition status) were not significantly different between both groups which show comparable conditions at baseline. Therefore, the outcome of this study is most likely to be due to the intervention.

\section{Nutrition education program on nutritional status of subjects}

Table 2 shows the nutritional status of subjects in the intervention and control groups. Nutritional status of subjects based on height-for-age z-score (HAZ) at baseline and end-line was not significantly different between intervention and control groups. Height is a portrayal of long-term nutritional status. Therefore, it requires a longer time to change. Thus, height change only within 14 weeks of the intervention period would not be significant. The prevalence of stunting and severe stunting in the intervention group (17.9\%) and control group (17.8\%) at end-line was classified as a mild public health problem. It was also lower compared to the national prevalence $(25 \%)$ in adolescents (5).

Table 2. Nutritional status of subjects in intervention and control groups

\begin{tabular}{llll}
\hline Indicators & $\begin{array}{l}\text { Intervention } \\
(\mathrm{n}=112)\end{array}$ & Control $(\mathrm{n}=129)$ & $\mathrm{p}$-value \\
\hline $\begin{array}{l}\text { Height-for-age (baseline) } \\
\text { Height-for-age status (baseline), } \\
\mathrm{n}(\%)\end{array}$ & $-1.3 \pm 0.8$ & $-1.3 \pm 0.8$ & 0.760 \\
$-\quad$ Severe stunting & $1(0.9)$ & & 0.803 \\
$-\quad$ Stunting & $20(17.9)$ & $26(1.6)$ & \\
\end{tabular}




\begin{tabular}{|c|c|c|c|}
\hline Indicators & $\begin{array}{l}\text { Intervention } \\
(\mathrm{n}=112)\end{array}$ & Control $(n=129)$ & $\mathrm{p}$-value \\
\hline - Normal & $91(81.2)$ & $101(78.3)$ & \\
\hline Height-for-age (end-line) & $-1.3 \pm 0.8$ & $-1.3 \pm 0.8$ & 0.773 \\
\hline $\begin{array}{l}\text { Height-for-age status (end-line), } \\
\mathrm{n}(\%)\end{array}$ & & & 0.406 \\
\hline - $\quad$ Severe stunting & $0(0.0)$ & $2(1.6)$ & \\
\hline - $\quad$ Stunting & $19(17.0)$ & $23(17.8)$ & \\
\hline - Normal & $93(83.0)$ & $104(80.6)$ & \\
\hline BMI-for-age (baseline) & $-0.2 \pm 1.0$ & $-0.3 \pm 1.1$ & 0.898 \\
\hline $\begin{array}{l}\text { BMI-for-age status (baseline), } \mathrm{n} \\
(\%)\end{array}$ & & & 0.743 \\
\hline - Severe wasting & $0(0.0)$ & $1(0.8)$ & \\
\hline - Wasting & $2(1.8)$ & $4(3.1)$ & \\
\hline - Normal & $98(87.5)$ & $107(82.9)$ & \\
\hline - Overweight & $9(8.0)$ & $14(10.9)$ & \\
\hline - Obese & $3(2.7)$ & $3(2.3)$ & \\
\hline BMI-for-age (end-line) & $-0.3 \pm 1.0$ & $-0.3 \pm 1.1$ & 0.859 \\
\hline $\begin{array}{l}\text { BMI-for-age status (end-line), } \mathrm{n} \\
(\%)\end{array}$ & & & 0.908 \\
\hline - $\quad$ Severe wasting & $1(0.9)$ & $2(1.6)$ & \\
\hline - Wasting & $3(2.7)$ & $5(3.9)$ & \\
\hline - Normal & $98(87.4)$ & $108(83.7)$ & \\
\hline - Overweight & $7(6.3)$ & $11(8.5)$ & \\
\hline - Obese & $3(2.7)$ & $3(2.3)$ & \\
\hline
\end{tabular}

Nutritional status of subjects based on body mass index-for-age z-score (BAZ) was not significantly different between intervention and control group, at baseline and end-line. A similar study that conducted a 3-month nutrition education program in Bengazhi City showed no significant changes in BMI and also physical activity among adolescents (20). This is possibly due to the limited time of exposure towards health and nutrition messages. A meta-analysis by Harris et al. (21) also stated that interventions on physical activity held in schools for six months showed no changes in BMI among elementary students. Hence, suggesting that students require a longer time of exposure towards health and nutrition.

Prevalence of wasting and severe wasting (end-line) in the intervention group and control group were lower than the national prevalence, which was $8.7 \%$ in adolescents aged $13-15$ years and $8.1 \%$ in adolescents aged 16-18 years (5). The prevalence of wasting, severe wasting, overweight, and obesity at the end-line was categorized as a low public health problem (22). Findings were also similar with the prevalence of overweight and obesity (end-line) which were lower compared to the national prevalence, which was $16 \%$ in adolescents aged $13-15$ years and 13.5\% in adolescents aged 16-18 years (5).

\section{Nutrition education program on hemoglobin level and anemia status of subjects}

The average hemoglobin level of subjects in the intervention group was lower than the control group at baseline (Table 3), but still within the normal range. The prevalence of anemia at baseline was higher in the intervention group (35.7\%) than in the control group (27.9\%). Although there were significant differences in hemoglobin level, however, the anemia status was comparable at baseline $(\mathrm{p}=0.213)$. At end-line, the average hemoglobin level of the intervention group was higher than the control group. Anemia prevalence at end-line decreased in the intervention group whereas it increased in the control group to be classified as a severe public health problem. There were significant differences in anemia prevalence between the intervention and control group at end-line $(p<0.05)$. The 
prevalence of anemia in both groups was higher than the national prevalence of anemia for female adolescents which was 32\% (5). Based on WHO classification for significant public health problem (17) anemia prevalence in both groups is classified as a moderate public health problem.

Table 3. Hemoglobin $(\mathrm{Hb})$ level of subjects in intervention and control groups $(n=241)$

\begin{tabular}{lllll}
\hline No & Indicators & $\begin{array}{l}\text { Intervention } \\
(\mathrm{n}=112)\end{array}$ & Control $(\mathrm{n}=129)$ & $\mathrm{p}$-value \\
\hline 1 & Hb baseline $(\mathrm{g} / \mathrm{dl})$ & $12.2 \pm 1.5$ & $12.5 \pm 1.2$ & $0.038^{*}$ \\
\hline 2 & Anemia status (baseline), $\mathrm{n}(\%)$ & & \\
& $-\quad$ Yes & $40(35.7)$ & $36(27.9)$ & 0.213 \\
& $-\quad$ No & $72(64.3)$ & $93(72.1)$ & \\
\hline 3 & Hb end-line (g/dl) & $12.6 \pm 1.51$ & $12.0 \pm 1.3$ & $<0.001^{*}$ \\
\hline 4 & Anemia status (end-line), $\mathrm{n}(\%)$ & & & $0.009^{*}$ \\
& $-\quad$ Yes & $28(25.0)$ & $53(41.1)$ & \\
& $-\quad$ No & $84(75.0)$ & $76(58.9)$ & \\
\hline
\end{tabular}

${ }^{*} \mathrm{p}$ value significant $(\mathrm{p}<0.05)$

To confirm the positive effect of nutrition education towards anemia status, we adjusted the findings for confounding variables that have been shown to have significant differences among the two groups. Our logistic regression analysis confirmed that even after adjusting for confounders, there was a significant effect towards anemia at end line. Those who did not receive the nutrition education program have 3.6 times the risk of having anemia compared to those in the intervention group.

Table 4. The effect of nutrition education towards anemia

\begin{tabular}{lccc}
\hline Time & Adjusted OR* & $95 \% \mathrm{CI}$ & $\mathrm{p}$-value \\
\hline Baseline & 1.584 & $0.7-3.6$ & 0.268 \\
\hline Endline & 3.688 & $1.5-8.9$ & 0.004 \\
\hline
\end{tabular}

*Adjusted for confounding variables: grade, mother and father's education level and pocket money

Hemoglobin level alteration in this study is possibly due to the effect of nutrition education given by teachers in this program. Through nutrition and health education, subjects were able to have a better knowledge of food high in iron to prevent anemia. Similar findings were found from a study in Malaysia, where a multiple-arm intervention study involving nutrition education was applied among adolescent students. At 6-month of the intervention, it was found that the group only receiving nutrition education and the group receiving a combination of nutrition education and supplementation showed a consistent increase in hemoglobin level as opposed to the group who only received supplementation (7). Biochemical changes are the first signs of nutrient deficiency which reflects the depletion of nutrient stores in the body. Only when this condition reaches a severe state and over a prolonged period of time, then it will manifest in clinical signs of malnutrition and consequently impair the growth (23). The stages of malnutrition explain why the intervention was able to result in significant changes in hemoglobin level and anemia prevalence, however, did not lead to anthropometric improvements. Longer duration of nutrition education and diet improvements will most likely lead to changes in both biochemical indicators and nutrition status.

Despite the positive effect of the nutrition education towards anemia status, the findings of the study need to be carefully interpreted due to a limitation of the study. The researchers were not able to match the control and intervention group based on the social-economic characteristics These includes variables such as grade, pocket money, and parent's education level. However, after adjusting for the confounding variables, we were still able to confirm the positive effect of the nutrition education program on anemia status. 


\section{Conclusion}

The study demonstrated that a 14-week nutrition and health education lead by teachers was able to improve the anemia status of adolescent girls compared to baseline and the control group. Hence, providing evidence that school-based nutrition education is beneficial to prevent anemia and should be considered at a wider scale. Currently, nutrition education is not inserted as part of the national curriculum. This study provides evidence of the effectiveness of school-based nutrition education programs towards the anemia status of adolescent girls and consequently supports nutrition education to be included in the national curriculum. Similar studies with a longer duration of time are suggested to be conducted to confirm the positive impact of nutrition education towards nutrition status of adolescents.

\section{Acknowledgment}

The authors would like to thank the teachers who were involved in the study and also SEAMEO RECFON who has funded the study under contract number 303/PPK/SEAMEO RECFON/III/2017.

\section{References}

1. Bajracharya A, Psaki S-R, Sadiq M. Child marriage, adolescent pregnancy and school dropout in South Asia, report by the Population Council for the United Nations Children's Fund Regional Office for South Asia. Kathmandu; Nepal. 2019.

2. Nove A, Matthews Z, Neal S, Camacho A-V. Maternal mortality in adolescents compared with women of other ages: Evidence from 144 countries. The Lancet Global Health. 2014 2(3):e155-64.

3. Ruel M-T, Alderman H. Series Maternal and Child Nutrition 3 Nutrition-sensitive interventions and programmes: how can they help to accelerate progress in improving maternal and child nutrition?. The Lancet. 2013.

4. Savage A, Februhartanty J, Worsley A. Adolescent women as a key target population for community nutrition education programs in Indonesia. Asia Pacific Journal of Clinical Nutrition. 2017 26(3):484-93.

5. National Institute of Health Research and Development Republic of Indonesia, Institute IHRI. Basic Health Survey. Jakarta; 2018.

6. Wang D, Stewart D, Chang C, Shi Y, Chang Chun, Shi Y, et al. Effect of a school-based nutrition education program on adolescents' nutrition-related knowledge, attitudes and behaviour in rural areas of China. Environmental Health and Preventive Medicine. 2015 Jul 1 20(4):271-8.

7. Yusoff H, Daud W-N-W, Ahmad Z. Nutrition education and knowledge, attitude and hemoglobin status of Malaysian adolescents. The Southeast Asian journal of tropical medicine and public health. 2012 43(1):192200.

8. Februhartanty J. Nutrition education: it has never been an easy case for Indonesia. Food and Nutrition Bulletin. 2005 June(26(2 Suppl 2)):S267-74.

9. Rachman P-H, Mauludyani A-V-R, Ekawidyani K-R, Februhartanty J. Barriers of Implementing a Nutrition Education Program for Adolescents in Rural Indonesian Schools. Malaysian Journal of Medicine and Health Sciences. 2020 16(SUPP6):2636-9346.

10. McCalla J-R, Juarez C-L, Williams L-E, Brown J, Chipungu K, Saab P-G. Promoting Healthy Lifestyle Behaviors: The Heart Smart Discussion Activity. J Sch Health. 2012 82(12):572-6.

11. SEAMEO Secretariat. Action Agenda for the SEAMEO 7 Priority Areas. Bangkok; 2018.

12. Kabahenda M-K. Effect of Nutrition Education on Nutritional Status and Growth of Young Children in Western Uganda. The University of Georgia. 2006.

13. Haldar D, Chatterjee T, Sarkar A, Bisoi S, Biswas A-K, Sardar J-C. A study on impact of school-based bealth and nutrition education in control of nutritional anemia among primary school children in rural West Bengal. Indian Journal of Community Medicine. 2012 Oct 37(4):259-62.

14. Rachman P-H, Mauludyani A-V-R, Ekawidyani K-R. Effectiveness of nutrition and health education module on acceptance, nutritional knowledge, attitude, practice and nutritional status of female adolescents in Ciampea Sub District Bogor. 2017.

15. SEAMEO RECFON. Buku Pegangan dan Kumpulan Rencana Ajar Untuk Guru Sekolah Menengah Pertama South East Asian Ministers of Education Organization Regional Centre for Food and Nutrition (SEAMEO RECFON). Jakarta: Southeast Asian Ministers of Education Organization Regional Center for Food and Nutrition; 2016.

16. WHO. WHO Child Growth Standards, Methods and development. World Health Organization. Geneva, Switzerland; 2006. 
17. WHO. Haemoglobin concentrations for the diagnosis of anaemia and assessment of severity. Vitamin and Mineral Nutrition Information System. Geneva: World Health Organization; 2011 1-6.

18. Ding D, Sallis J-F, Norman G-J, Saelens B-E, Sion, Harris K, et al. Community Food Environment, Home Food Environment, and Fruit and Vegetable Intake of Children and Adolescents. Journal of Nutrition Education and Behavior. 2012 44:634-8.

19. Alkerwi A, Vernier C, Sauvageot N, Crichton G-E, Elias M-F. Demographic and socioeconomic disparity in nutrition: application of a novel Correlated Component Regression approach. Open. 2015 5:6814.

20. Sachithananthan V, Buzgeia M, Awad F, Omran R, Faraj A. Impact of nutrition education on the nutritional status. Nutrition and Food Science. 2012 May 42(3):173-80.

21. Harris K-C, Kuramoto L-K, Schulzer M, Retallack J-E. Effect of school-based physical activity interventions on body mass index in children: A meta-analysis. CMAJ. 2009 Mar 31 180(7):719-26.

22. de Onis M, Borghi E, Arimond M, Webb P, Croft T, Saha K, et al. Prevalence thresholds for wasting, overweight andstunting in children under 5 years. Public Health Nutrition. 2018 22(1):175-9.

23. Pfeiffer C-M, Schleicher R-L, Caldwell K-L. Biochemical Indices. In: Encyclopedia of Human Nutrition. Elsevier Inc; 2012. p. 156-74. 